OPEN ACCESS

Edited by:

Tarun Belwal,

Zhejiang University, China

Reviewed by:

Tao Feng,

Shanghai Institute of

Technology, China

Olivia Rodrigues Pereira,

Polytechnic Institute of Bragança

(IPB), Portugal

${ }^{*}$ Correspondence:

He Yuanqing

yqhe@ujs.edu.cn

Specialty section:

This article was submitted to Nutrition and Food Science

Technology,

a section of the journa

Frontiers in Nutrition

Received: 29 March 2021

Accepted: 27 May 2021

Published: 21 June 2021

Citation:

Yuanqing $H$, Pengyao $Y$, Yangyang $D$, Min $C$, Rui $G$, Yuqing $D$, Haihui $Z$ and

Haile $M$ (2021) The Preparation,

Antioxidant Activity Evaluation, and Iron-Deficient Anemic Improvement of

Oat (Avena sativa L.)

Peptides-Ferrous Chelate.

Front. Nutr. 8:687133.

doi: 10.3389/fnut.2021.687133

\section{The Preparation, Antioxidant Activity Evaluation, and Iron-Deficient Anemic Improvement of Oat (Avena sativa L.) Peptides-Ferrous Chelate}

\author{
He Yuanqing ${ }^{1,2 *}$, Yang Pengyao ${ }^{1}$, Ding Yangyang ${ }^{3}$, Chen Min ${ }^{1}$, Guo Rui ${ }^{1}$, Duan Yuqing ${ }^{1}$, \\ Zhang Haihui ${ }^{1}$ and Ma Haile ${ }^{1}$
}

\footnotetext{
${ }^{1}$ College of Food Science and Biological Engineering, Jiangsu University, Zhenjiang, China, ${ }^{2}$ The Laboratory Animal Research Center, Jiangsu University, Zhenjiang, China, ${ }^{3}$ School of the Environment and Safety Engineering, Jiangsu University, Zhenjiang, China
}

Iron-chelating peptides have been widely considered as one of the best iron supplements to alleviate the iron deficiency. In this study, a novel oat peptides-ferrous (OP- $\mathrm{Fe}^{2+}$ ) chelate was prepared from antioxidant oat peptides obtained in the laboratory of the authors. The optimal preparation condition was obtained through the single-factor and response surface methodology, and the chelating rate could reach up to $62.6 \%$. After chelation, the OP-Fe ${ }^{2+}$ chelate exhibited a significantly higher 2,2-diphenyl-1picrylhydrazyl radical scavenging activity than oat peptides. It was discovered that the hemoglobin concentration and the number of red blood cell levels in OP-Fe ${ }^{2+}$-treated iron-deficient anemic (IDA) rats were significantly higher than untreated IDA rats. The $\mathrm{OP}-\mathrm{Fe}^{2+}$ chelate could also improve the hypertrophy of the spleen, serum iron (SI), total iron and binding capacity, and serum ferritin levels in the IDA rats. In addition, the OP$\mathrm{Fe}^{2+}$ treatment significantly increased the antioxidant activities of super oxidase and glutathione in the liver homogenate of the IDA rats. Therefore, the OP-Fe ${ }^{2+}$ chelate is an effective type of iron supplement for IDA rats, which could be a promising source with anti-anemia and antioxidant activity.

Keywords: iron supplement, peptides-ferrous chelate, oat peptide, iron-deficient anemic, antioxidant activity

\section{HIGHLIGHTS}

- After chelation, oat peptides-ferrous chelate $\left(\mathrm{OP}-\mathrm{Fe}^{2+}\right)$ exhibited a signif-icantly higher 2, 2-diphenyl-1-picrylhydrazyl (DPPH) radical scavengingactivity than oat peptides (OP).

- OP- $\mathrm{Fe}^{2+}$ chelate showed a good iron supplemental effect on IDA rats.

- $\mathrm{OP}-\mathrm{Fe}^{2+}$ was helpful to restore the antioxidant capacity of anemic rats.

- OP- $\mathrm{Fe}^{2+}$ chelate could avoid the body damage caused by the iron deficiency anemia. 


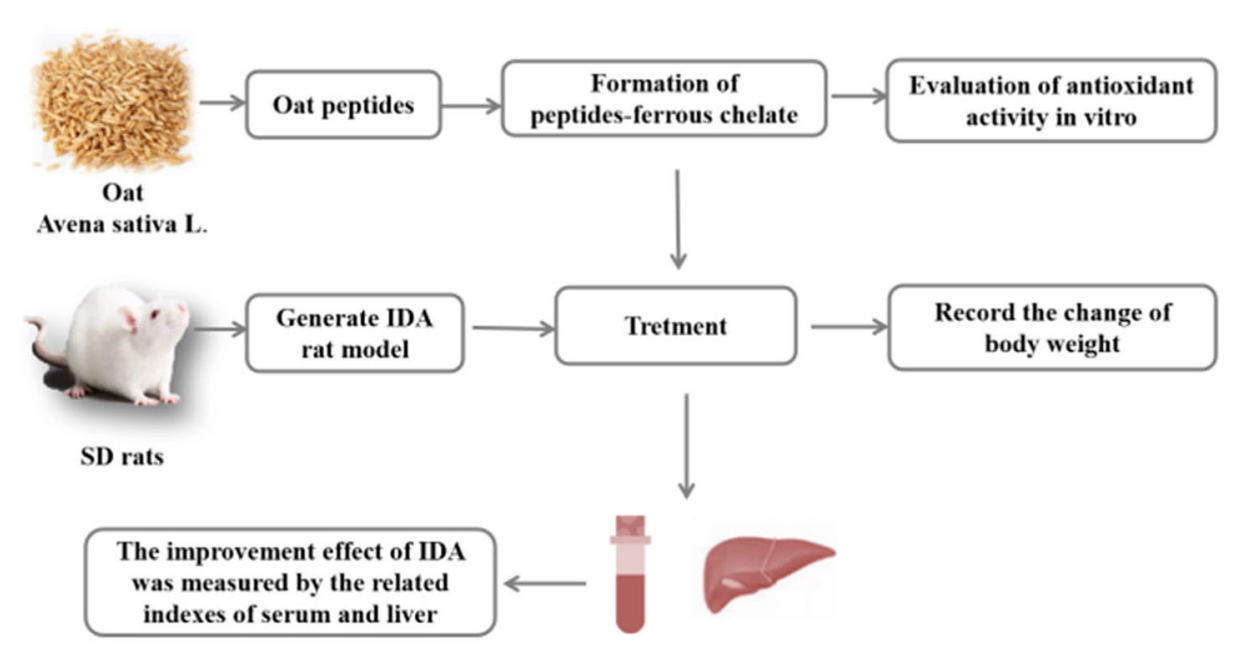

GRAPHICAL ABSTRACT | An overview of the experiment. In this study, OP-Fe ${ }^{2+}$ was prepared from the antioxidant oat peptides. After chelation, the antioxidant activities of OP-Fe ${ }^{2+}$ is higher than OP. In addition, animal experiments indicated that $\mathrm{OP}-\mathrm{Fe}^{2+}$ can be used as an effective iron supplement and antioxidant.

\section{INTRODUCTION}

Iron, a kind of essential trace element for humans and animals, participates in multiple biological processes, such as protein and DNA synthesis (1). Iron works as a vital part of cytochrome, hemoglobin, and enzymes, and plays an important role in transporting and storing oxygen for breathing and metabolism (2). Insufficient iron absorption or iron loss from dietary sources can lead to iron deficiency (1). Iron deficiency may cause anemia, with common symptoms, such as fatigue, dizziness, and irritability. Iron deficiency anemia has been regarded as a global problem that troubles one third of the global population, particularly infants, pregnant women, and the elderly (3). Iron deficiency anemia affects more than 1.2 billion individuals worldwide, and iron deficiency in the absence of anemia is even more frequent (4). The most common manifestations are pregnancy accidents as well as developmental delay and cognitive impairment in young children. Iron deficiency could result in a series of dysfunctions, such as chronic fatigue and weakened immune function in adults (5).

Many iron supplements have been exploited to solve this emergency problem. The use of inorganic ferrous-iron salt has been limited by side effects and low bioavailability (6, 7). Recently, bioactive peptides derived from food protein as a kind of new metal ion chelating agent have attracted the interest of people (8). Peptide- $\mathrm{Fe}^{2+}$, with greater bioactivity, high absorption, and no side effects has been considered as one of the best iron supplements to improve iron deficiency (9). Some ferrous-iron chelating peptides have been discovered and characterized, which can be used as iron supplements. For example, ferrous-iron-chelating peptides from Alaska pollock frames (APFP-Fe) are a useful iron source for improving iron nutritional status in iron deficiency anemic rats (10). Chickpea peptides, through metal chelation, may increase iron solubility and bioavailability, and improve iron absorption (11). Hairtail protein hydrolysate, through metal chelation, showed an antifatigue effect (12). The peptide from barley protein could enhance the level of iron absorption and ferritin in Caco-2 cells (8). However, little attention has been paid to the function of the ferrous-iron-chelating peptide from oat.

As we all know, oat has the highest amount of proteins among cereals, which is low price and easy to obtain (13). In addition, the biological value (64.9\%), net protein utilization $(65.7 \%)$, and protein efficiency ratio (2.25) of oat protein are significantly higher compared with other cereals (14). These data mean that the oat protein will have a higher application prospect than other plant proteins. Oat bioactive peptides have been proved to have a good antioxidant activity (8), and hypotensive and hypoglycemic activities $(15,16)$. Karas et al. (17) also found that oat peptides are structurally similar to epidermal cell growth factor (EGF), which could be easily absorbed by the skin, and then improve skin metabolism. The application of oat peptides is significant for the protection of human health. Oat bioactive peptides may be used to prepare OP-Fe ${ }^{2+}$, which could increase chelation efficiency. Moreover, oat bioactive peptides could prevent $\mathrm{Fe}^{2+}$ oxidation in the gastrointestinal tract after being ingested, and increase the bioavailability of $\mathrm{Fe}^{2+}$. The purpose of this study was to obtain the best conditions for the preparation of OP-Fe ${ }^{2+}$ and confirm its iron supplement and antioxidative function by in vitro and in vivo methods.

\section{MATERIALS AND METHODS}

\section{Materials}

Oat was purchased from Shijiazhuang Lingfeng Agricultural and Sideline Products Development Co., Ltd. (Hebei, China). Alkaline protease with a reported activity of $2.4 \mathrm{AU} \mathrm{g}^{-1}$ was purchased from Novozym Biotechnology Co., Ltd. (Henan, China). Ferrous chloride (molecular weight 198.83) was obtained from Sinopharm Chemical Reagent Co., Ltd. (Shanghai, China). 
Other chemical reagents used in this study were of analytical grade and commercially available.

\section{Preparation of Oat Peptides}

The oat peptides were prepared and obtained in the laboratory of the authors. Oat protein was obtained through methods of alkaline extraction and acid precipitation. The hydrolysis reaction was proceed using alkaline protease under optimized conditions as follows: $2.5 \%$ (wt/wt, defined as enzyme mass/substrate mass $\times 100 \%), 9.5(\mathrm{pH}), 55^{\circ} \mathrm{C}$ (temperature) and $2 \mathrm{~h}$ (time). Then, the hydrolysate was heated at $90^{\circ} \mathrm{C}$ for $15 \mathrm{~min}$ to inactivate the enzyme followed by centrifugation at $1,350 \times$ $\mathrm{g}$ for $20 \mathrm{~min}$ at room temperature to obtain the supernatant. The fraction with formula weight $<3 \mathrm{kDa}$ in the hydrolysate was collected with the ultra-filtration membrane $(3 \mathrm{kDa})$. After freeze-drying, the obtained oat peptides (OPs) were stored at $-20^{\circ} \mathrm{C}$ for the next step.

\section{Preparation of Peptides-Ferrous}

Single-factor tests were performed to optimize chelating conditions (18). First, OP solutions with different concentrations $(2,3,4,5$, and $6 \%)$ were prepared, and $0.5 \%$ ascorbic acid was added in the solution to prevent the oxidation of $\mathrm{Fe}^{2+}$. Then, $\mathrm{FeCl}_{2}$ was added to form OP-Fe ${ }^{2+}$ with different mass ratios in OP and $\mathrm{FeCl}_{2}$ (OP-FeCl 2 ratios: 1:1, 2:1, 3:1, 4:1, 5:1, and 6:1). The mixture was incubated in water bath equipment at different $\mathrm{pH}(3,4,5,6$, and 7$)$ and temperature $\left(20,30,40,50\right.$, and $\left.60^{\circ} \mathrm{C}\right)$ for different lengths of time (20,30, 40, 50, and $60 \mathrm{~min})$. After chelation, the supernatant was collected after centrifugation at $1,350 \times \mathrm{g}$ for $10 \mathrm{~min}$ followed by the addition of $95 \%$ ethanol to the supernatant (ethanol: supernatant $=6: 1$ ). The mixed solution was left to settle statically for $1 \mathrm{~h}$. The sediment $\left(\mathrm{OP}-\mathrm{Fe}^{2+}\right)$ was collected after centrifugation at $6,010 \times \mathrm{g}$ for $20 \mathrm{~min}$ and then washed with $95 \%$ ethanol 5 times to remove excess $\mathrm{Fe}^{2+}$. The OP$\mathrm{Fe}^{2+}$ powder was collected after the sediment was freeze-dried. The chelating ratio (CR) was calculated by the following formula:

$$
C R=(B / A) \times 100 \%
$$

where, A (mg) represents total content of $\mathrm{Fe}^{2+}$ in the reaction system; $\mathrm{B}(\mathrm{mg})$ represents the content of $\mathrm{Fe}^{2+}$ in the OP$\mathrm{Fe}^{2+}$ chelate.

\section{Experiment Design of Response Surface Methodology}

The ranges of the factors were determined based on the results of the single factor experiment. A Box-Behnken experimental design with three factors and three levels was chosen to optimize the chelation conditions of $\mathrm{OP}-\mathrm{FeCl}_{2}$. The chelating rate was used as the response value. Factors and levels designed for RSM, such as $\mathrm{pH}(5,6,7), \mathrm{OP}-\mathrm{FeCl}_{2}$ ratio $(3,4,5)$, and $\mathrm{OP}$ concentration (2, $3,4 \%)$ are shown in Table $\mathbf{1 .}$

\section{Activity of Scavenging 2,2-diphenyl-1-picrylhydrazyl Radicals}

The activity of scavenging DPPH radicals was measured according to the reference method (19). Sample solutions (1 ml) with different concentrations $(6.25,12.5,25,50 \mathrm{mg} / \mathrm{ml})$ were
TABLE 1 | Factors and levels of RSM.

\begin{tabular}{lccr}
\hline Factors & \multicolumn{3}{c}{ Levels } \\
\cline { 2 - 4 } & $\mathbf{- 1}$ & $\mathbf{0}$ & $\mathbf{1}$ \\
\hline (A) $\mathrm{pH}$ & 5 & 6 & 7 \\
(B) $\mathrm{OP}$ concentration & 2 & 3 & 4 \\
(C) $\mathrm{OP}-\mathrm{FeCl}_{2}$ ratio & 3 & 4 & 5 \\
\hline
\end{tabular}

blended with a $4-\mathrm{ml} \mathrm{DPPH}$ ethanol solution $(0.12 \mathrm{mmol} / \mathrm{L}$, prepared with $95 \%$ ethanol), and then kept in the dark for $30 \mathrm{~min}$ at $25^{\circ} \mathrm{C}$. Absorbance was measured at $517 \mathrm{~nm}$ with a microplate spectrophotometer (Biotek Instruments, Winooski, VT, United States). The activity of scavenging DPPH radicals was calculated as follows:

The activity of scavenging $D P P H$ radicals $(\%)=[1$

$$
\left.-\left(A_{\mathrm{i}}-A_{\mathrm{j}}\right) / A_{\mathrm{C}}\right] \times 100 \% \text {, }
$$

$\left(A_{i}-A_{j}\right)$ and $A_{C}$ represent the absorbance of the sample and the control, respectively.

\section{Activity of Scavenging Hydroxyl Radicals}

The activity of scavenging hydroxyl radicals was measured according to the following method: solutions with different concentrations of OP $(3.125,6.25,12.5,25$, and $50 \mathrm{mg} / \mathrm{ml})$ and OP-Fe ${ }^{2+}(3.125,6.25,12.5,25$, and $50 \mathrm{mg} / \mathrm{ml})$ complex were prepared. Sample solutions $(2 \mathrm{ml})$ with different concentrations blended with $\mathrm{FeSO}_{4}(0.5 \mathrm{ml}, 9 \mathrm{mmol} / \mathrm{L}$, prepared with ethanol), salicylic acid $(0.5 \mathrm{ml}, 9 \mathrm{mmol} / \mathrm{L}$, prepared with ethanol), and $\mathrm{H}_{2} \mathrm{O}_{2}(0.5 \mathrm{ml}, 0.15 \%)$ were incubated at $37^{\circ} \mathrm{C}$ for $30 \mathrm{~min}$. Then, absorbance was measured at $510 \mathrm{~nm}$.

\section{Animal Experiments and Experimental Design}

The animal experiment was approved by the Institutional Animal Care and Use Committees of Jiangsu University (UJSIACUC-2020072201). Sixty male Sprague-Dawley (SD) rats (No. 202009460) weighing 40-50 g were purchased from Nanjing Medical University [SCXK (SU) 2016-0002] and fed at the Laboratory Animal Research Center of Jiangsu University [SYXK (SU) 2018-0053, the temperature at $20-26^{\circ} \mathrm{C}$, the humidity of $40-$ $70 \%$, the diurnal cycle of $12 \mathrm{~h}$ ]. Rats achieved distilled deionized water in the period of the study freely. After adaptation for 3 days, the 60 rats were randomly assigned to six groups $(n=$ 10 /group). Ten rats were designated as the control group fed with a standard diet (Synergetic Bioengineering Co. Ltd., Nanjing, China) throughout the whole experimental period. Fifty rats were fed with an iron-deficient diet $(5 \mathrm{mg} \mathrm{Fe} / \mathrm{kg}$ diet, Synergetic Bioengineering Co. Ltd., Nanjing, China) for 21 days to generate an IDA rat model. After 21 days, the blood of model rats ( $n$ $=50$ ) was collected by orbital venipuncture into anticoagulant blood vessels for the hematological test, and IDA was defined as hemoglobin (Hb) values below $100 \mathrm{~g} / \mathrm{L}$ (10). After the IDA rat model was established, the control group was still fed with a standard diet, and 50 IDA rats were randomly subdivided into five groups and still fed with an iron-deficient diet $(5 \mathrm{mg}$ $\mathrm{Fe} / \mathrm{kg} /$ day). Out of five groups, three were administered OP-Fe ${ }^{2+}$ 
TABLE 2 | Summary of the experiment design and the doses of OP-Fe $2+$ or $\mathrm{Fecl}_{2}$ on rats.

\begin{tabular}{|c|c|c|}
\hline Group & Diet & Gavage \\
\hline Control Group (CG) & Standard diet & $\begin{array}{l}\text { Sterile water (5 } \\
\mathrm{ml} / \mathrm{kg} / \text { day) }\end{array}$ \\
\hline Model Group (MG) & $\begin{array}{l}\text { Iron-deficient } \\
\text { diet }\end{array}$ & $\begin{array}{l}\text { Sterile water (5 } \\
\mathrm{ml} / \mathrm{kg} / \text { day) }\end{array}$ \\
\hline $\begin{array}{l}\text { OP-Fe }{ }^{2+} \text { Low Dose } \\
\text { Group (OPFL) }\end{array}$ & $\begin{array}{l}\text { Iron-deficient } \\
\text { diet }\end{array}$ & $\begin{array}{l}\mathrm{OP}-\mathrm{Fe}^{2+}(1.0 \mathrm{mg} \\
\mathrm{Fe} / \mathrm{kg} / \text { day })\end{array}$ \\
\hline $\begin{array}{l}\text { OP-Fe }{ }^{2+} \text { Medium Dose } \\
\text { Group (OPFM) }\end{array}$ & $\begin{array}{l}\text { Iron-deficient } \\
\text { diet }\end{array}$ & $\begin{array}{l}\mathrm{OP}-\mathrm{Fe}^{2+}(3.0 \mathrm{mg} \\
\mathrm{Fe} / \mathrm{kg} / \text { day })\end{array}$ \\
\hline $\begin{array}{l}\text { OP-Fe }{ }^{2+} \text { High Dose } \\
\text { Group (OPFH) }\end{array}$ & $\begin{array}{l}\text { Iron-deficient } \\
\text { diet }\end{array}$ & $\begin{array}{l}\text { OP-Fe }{ }^{2+}(5.0 \mathrm{mg} \\
\mathrm{Fe} / \mathrm{kg} / \text { day })\end{array}$ \\
\hline $\mathrm{FeCl}_{2}$ Group (FG) & $\begin{array}{l}\text { Iron-deficient } \\
\text { diet }\end{array}$ & $\begin{array}{l}\mathrm{FeCl}_{2} \text { (3.0 mg } \\
\mathrm{Fe} / \mathrm{kg} / \text { day) }\end{array}$ \\
\hline
\end{tabular}

The above grouping design was carried out after the successful establishment of IDA rat model.

and one $\mathrm{FeCl}_{2}$. The administration was intragastric, once a day for 21 days. The detail dose of each group is shown in Table 2. The ingredients of iron-deficient diet are casein (20\%), LCystine (3\%), corn starch (15\%), sucrose (54.999\%), ethoxyquin $(0.001 \%)$, corn oil $(5 \%)$, mineral mix s18703 (3.5\%), choline bitartrate $(0.2 \%)$, and vitamin mix v1001 (1\%).

\section{Hematological Test}

At the end of the experimental period, the rats fasted for $12 \mathrm{~h}$ before euthanasia. Blood samples were collected from the abdominal aorta and kept in tubes with an anticoagulant. The serum was separated by centrifugation at $1,850 \times \mathrm{g}$ for $15 \mathrm{~min}$ and stored at $-80^{\circ} \mathrm{C}$ for further analyses.

The hemoglobin value (HB), number of red blood cells (RBC), mean red cell volume (MCV), and mean red blood cell hemoglobin concentration (MCHC) were measured with an automated blood analyzer (Sysmex F-820, TOA Medical Electronics Co. Ltd., Kobe, Japan). The serum iron (SI) level and total iron and binding capacity (TIBC) were measured using the corresponding assay kits (Nanjing Jiancheng Bioengineering Institute, Nanjing, China). Meanwhile, serum ferritin (SF) was measured by a ferritin assay kit (Nanjing Jiancheng Bioengineering Institute, Nanjing, China). Serum ALT and AST were analyzed by Nanjing Kingmed for Clinical Laboratory using the Beckman AU5800 instrument (Beckman Coulter, Inc., Brea, CA, United States).

\section{Determination of Antioxidant Activity in vivo}

The activity of superoxide dismutase (SOD), glutathione (GPX), and malondialdehyde (MDA) levels in liver homogenate were measured with corresponding assay kits (Nanjing Jiancheng Bioengineering Institute, Nanjing, China).

\section{Organ Coefficient}

The spleen and liver were collected and weighed immediately. The liver was rapidly frozen in liquid nitrogen and then stored at $-80^{\circ} \mathrm{C}$ for the next step analysis. The relative weight of each organ was calculated based on the final body weight. The organ coefficient was counted as follows:

$$
\begin{aligned}
\text { Organ coefficient }(\mathrm{g} / 100 \mathrm{~g})= & \text { Organ weight } / \text { rat body weight } \\
& \times 100 .
\end{aligned}
$$

\section{Statistical Analysis}

Data were presented as mean $\pm \mathrm{SD}(n=10)$. Statistical processing and data analysis were performed using the SPSS software program (SPSS 17.0, SPSS Inc., Chicago, IL, United States) and GraphPad Prism 5.0 (GraphPad Software, San Diego, CA, United States).

One-way analysis of variance (ANOVA) followed by Duncan's new multiple range method was applied to analyze the statistical results. ANOVA data with $p<0.05$ were considered statistically significant.

\section{RESULTS}

\section{Results of Single Factor Experiment}

According to the results of the single factor experiment (Figures 1A-E), the optimal $\mathrm{pH}, \quad \mathrm{OP}-\mathrm{FeCl}_{2}$ ratio, OP concentration, temperature, and time are $6,4: 1,3 \%, 40^{\circ} \mathrm{C}$, and $30 \mathrm{~min}$, respectively. Three factors ( $\mathrm{pH}$, OP concentration, and $\mathrm{OP}-\mathrm{FeCl}_{2}$ ratio), which have a great influence on the chelating rate, were selected for further response surface optimization experiments.

\section{Results of Response Surface Methodology Experiment \\ Statistical Analysis and Model Fitting}

The chelating rate of $\mathrm{OP}-\mathrm{FeCl}_{2}$ was optimized by $\mathrm{RSM}$ using the Box-Behnken design method. Seventeen combinations were produced by the Box-Behnken design, and each combination was repeated three times, as shown in Table 3. The data of the chelating rate were analyzed by multiple regression to obtain the second-order polynomial equation:

$$
\begin{aligned}
\mathrm{R} 1= & 60.68-13.07 \mathrm{~A}+1.10 \mathrm{~B}+0.72 \mathrm{C}-3.35 \mathrm{AB}+8.05 \mathrm{AC} \\
& +4.75 \mathrm{BC}-18.72 \mathrm{~A}^{2}-2.52 \mathrm{~B}^{2}-3.66 \mathrm{C}^{2}
\end{aligned}
$$

where, $\mathrm{R} 1$ was chelating rate; $\mathrm{A}, \mathrm{B}$, and $\mathrm{C}$ represented $\mathrm{pH}, \mathrm{OP}$ concentration, $\mathrm{OP}-\mathrm{FeCl}_{2}$ ratio, respectively.

The statistical significance of the regression model was tested using F-test and $p$-value. The ANOVA for the response surface quadratic model was summarized in Table 4. The ideal regression equation and the high model significance were confirmed by its low $p$-value $(p<0.01)$ and lack of fit $(p=0.1021>$ $0.05)$. The correlation coefficient R2 of the model is 0.9668 , indicating that there is a high correlation between the predicted value and the measured value. The results showed that $\mathrm{pH}$ value had a significant effect on chelation rate, while the other factors had no significant effect. Among the three factors, the interaction between $\mathrm{pH}$ and polypeptide concentration was very significant, while the interaction between the other factors was not significant.

The 3D response surface is shown in Figures $2 \mathrm{~A}-\mathrm{C}$, which reflected the relationship between two independent variables. 

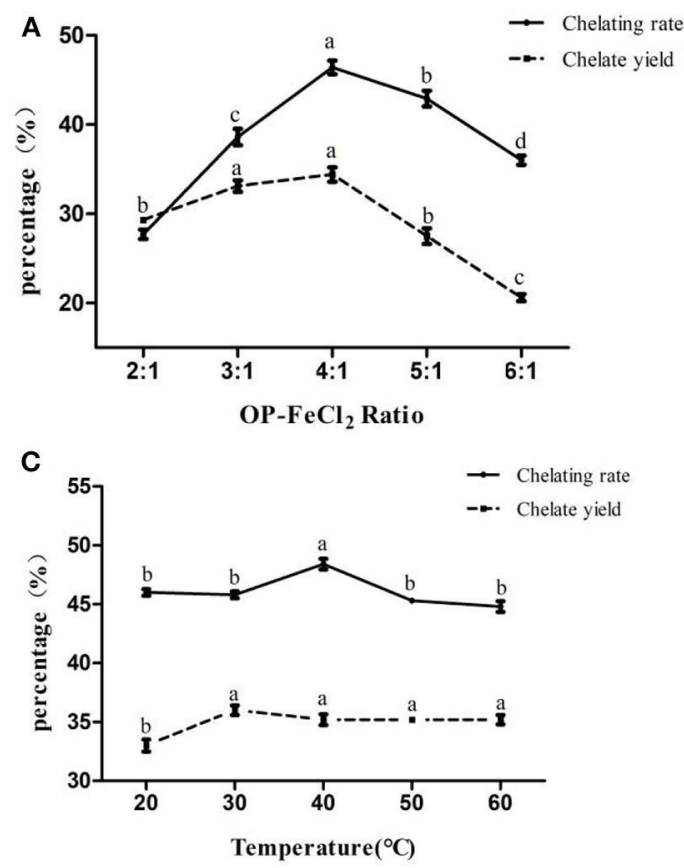

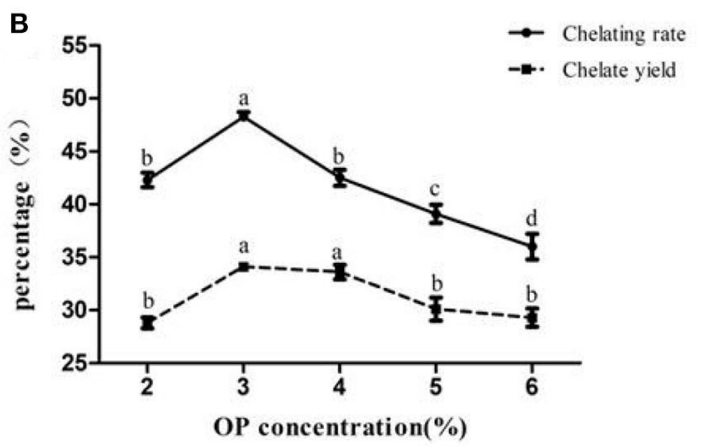

D

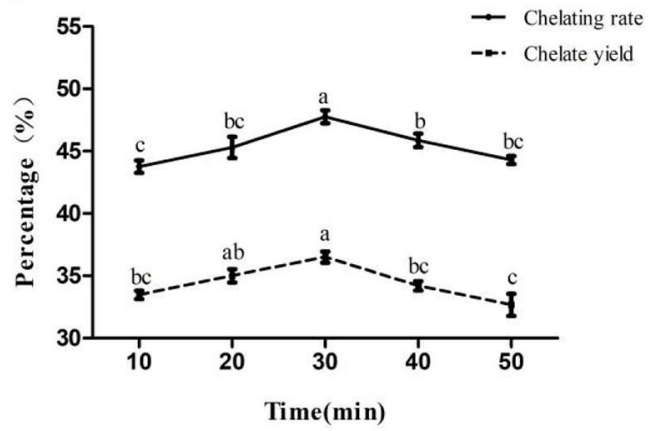

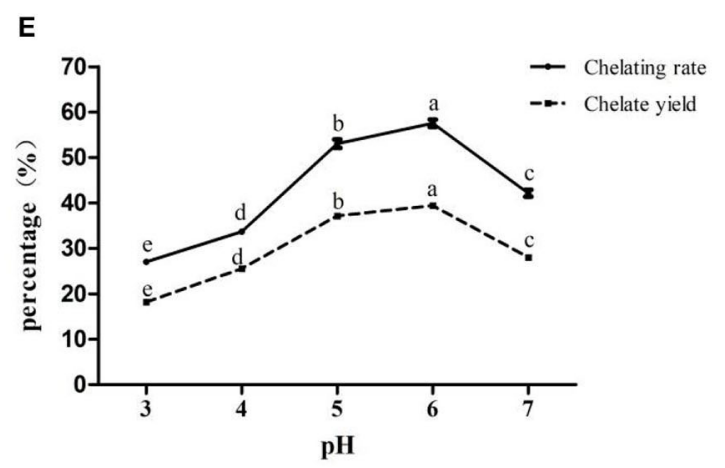

FIGURE 1 | Effects of different binding conditions on chelating rate and chelate yield (A:OP-FeCl2 ratio, B:OP concentration, C: Temperature, D: Time, E:pH). In the same index, different letters indicate that there are significant differences between different levels $(p<0.05)$, whereas, the same letters mean that there are no statistical differences between different levels $(p>0.05)$.

Figure $2 \mathrm{~A}$ represented the effects of $\mathrm{OP}-\mathrm{FeCl}_{2}$ ratio, $\mathrm{pH}$ and their interactions on the chelation rate of OP- $\mathrm{Fe}^{2+}$. Figure 2B represented the effects of $\mathrm{OP}$ concentration, $\mathrm{pH}$ and their interactions on the chelation rate of $\mathrm{OP}-\mathrm{Fe}^{2+}$. Figure 2C represented the effects of $\mathrm{OP}$ concentration, $\mathrm{OP}-\mathrm{FeCl}_{2}$ ratio and their interactions on the chelation rate of OP- $\mathrm{Fe}^{2+}$.

\section{Confirmative Tests}

The optimum preparation process of OP- $\mathrm{Fe}^{2+}$ for maximum chelation rate was obtained as follows: $\mathrm{pH}=5.5$, peptide:iron $=4.4: 1$, peptide concentration $=3 \%, 40^{\circ} \mathrm{C}, 20 \mathrm{~min}$. Under the above conditions, the chelating rate of OP$\mathrm{Fe}^{2+}$ predicted was $63.5 \%$. In order to verify the accuracy of these conditions, the experiment was repeated three times under the above-mentioned conditions, and the actual chelation rate of $\mathrm{OP}-\mathrm{Fe}^{2+}$ had reached $62.6 \%$. The error different from the theoretical calculation is about 0.9, which indicated that the predicted model could be used for the prediction of the chelating rate of $\mathrm{OP}-\mathrm{Fe}^{2+}$ totally.

\section{Determination of Antioxidant Activities}

2,2-diphenyl-1-picrylhydrazyl radical scavenging experiment has extensively been used to evaluate deoxidizing ability (20). As shown in Figure 3A, OP- $\mathrm{Fe}^{2+}$ had stronger 2,2-diphenyl-1picrylhydrazyl (DPPH) radical scavenging activity than OP at the same concentration. The $\mathrm{IC}_{50}$ of DPPH radical scavenging rate of $\mathrm{OP}$ and $\mathrm{OP}-\mathrm{Fe}^{2+}$ was 9.11 and $0.02 \mathrm{mg} / \mathrm{ml}$, respectively. It could be discovered from Figure 3B that $\mathrm{OP}-\mathrm{Fe}^{2+}$ also exhibited stronger activity of scavenging hydroxyl radical than $\mathrm{OP}$ at the concentration of $3.125 \mathrm{mg} / \mathrm{ml}$. The $\mathrm{IC}_{50}$ of hydroxyl radical scavenging of $\mathrm{OP}$ and $\mathrm{OP}-\mathrm{Fe}^{2+}$ was 3.06 and 1.61 $\mathrm{mg} / \mathrm{ml}$, respectively. 


\section{Body Weight Changes in Rats}

The changes in the rat body weight on experiment days $0,28,35,42$, and 52 are presented in Table 5. When the IDA model was successfully established (28 days), there was a statistical significance $(p<0.05)$ between the CG group and the other groups. After feeding of $\mathrm{OP}-\mathrm{Fe}^{2+}$ and $\mathrm{FeCl}_{2}$ diet for 52 days (administration for 3 weeks

TABLE 3 | Central composition test design and results.

\begin{tabular}{|c|c|c|c|c|}
\hline \multirow[t]{2}{*}{ Runs } & \multicolumn{3}{|c|}{ Factors } & \multirow{2}{*}{$\begin{array}{c}\text { Chelating } \\
\text { rate } \%\end{array}$} \\
\hline & A & B & C & \\
\hline 1 & 0 & 0 & 0 & 57.5 \\
\hline 2 & -1 & 0 & 1 & 46.7 \\
\hline 3 & 1 & 0 & 1 & 36.5 \\
\hline 4 & -1 & -1 & 0 & 45.9 \\
\hline 5 & 0 & 1 & -1 & 50.6 \\
\hline 6 & -1 & 1 & 0 & 59.0 \\
\hline 7 & 0 & 0 & 0 & 58.5 \\
\hline 8 & 1 & 1 & 0 & 26.3 \\
\hline 9 & -1 & 0 & -1 & 56.2 \\
\hline 11 & 0 & 0 & 0 & 62.8 \\
\hline 12 & 1 & -1 & 0 & 26.6 \\
\hline 13 & 1 & 0 & -1 & 13.8 \\
\hline 14 & 0 & 0 & 0 & 63.7 \\
\hline 15 & 0 & -1 & 1 & 48.9 \\
\hline 16 & 0 & 1 & 1 & 56.4 \\
\hline 17 & 0 & -1 & -1 & 62.1 \\
\hline
\end{tabular}

and 3 days), no significant differences were observed between the CG group and the other groups except the MG group. These results indicate that $\mathrm{OP}-\mathrm{Fe}^{2+}$ can supplement the need for iron of the body and reach the normal level.

\section{Organ Coefficients of Rats}

The organ coefficients of the rats in each group are shown in Figure 4A. The spleen coefficient levels of the MG group were significantly higher than those of the CG, OPFL, OPFM, $\mathrm{OPFH}$, and FG groups $(p<0.05)$. Meanwhile, there were no significant differences between the CG group and the OPFL, OPFM, OPFH, and FG groups ( $p>0.05)$. As shown in Figure 4B, the liver coefficient level of the MG group was significantly lower than that of the CG and OPFH groups $(p<0.05)$. No significant differences were found between the CG and OPFH groups $(p>0.05)$. These results indicated that OP$\mathrm{Fe}^{2+}$ could relieve hypertrophy of the spleen that was caused by anemia.

\section{Hematological Analysis}

Hematological indices, such as $\mathrm{Hb}, \mathrm{RBC}, \mathrm{MCV}$, and $\mathrm{MCHC}$ were measured, which could reflect the situations of iron deficiency. In the MG group, the level of $\mathrm{Hb}, \mathrm{RBC}$, and $\mathrm{MCV}$ were lower than that in the CG group (Figures 5A-C), $p<0.01$ ), suggesting that the model was built as expected successfully. $\mathrm{OP}-\mathrm{Fe}^{2+}$ treatment can significantly improve this change. After treatment with $\mathrm{OP}-\mathrm{Fe}^{2+}$ for 2 weeks, the $\mathrm{Hb}$ levels in the OPFM and OPFH groups were significantly increased by 65.9 and $67.1 \%$, respectively, when compared with the MG group (Figure 5A, $p<0.01$ ). As shown in Figure 5B, the RBC level of each treatment group reached the normal level $(p>0.05)$. There were no significant differences in MCV levels between the $\mathrm{CG}$ and OPFM groups and the FG group (Figure 5C, $p>0.05$ )

TABLE 4 | ANOVA for response surface quadratic model analysis of variance.

\begin{tabular}{|c|c|c|c|c|c|}
\hline Source & $\begin{array}{l}\text { Sum of } \\
\text { squares }\end{array}$ & df & Mean square & F value & $P$-value \\
\hline Model & 3401.74 & 9 & 377.97 & 22.63 & $0.0002^{\star \star}$ \\
\hline A & 1367.64 & 1 & 1367.64 & 81.90 & $<0.0001^{\star *}$ \\
\hline B & 9.68 & 1 & 9.68 & 0.58 & 0.4713 \\
\hline C & 4.20 & 1 & 4.20 & 0.25 & 0.6312 \\
\hline$A B$ & 44.89 & 1 & 44.89 & 2.69 & 0.1451 \\
\hline$A C$ & 259.21 & 1 & 259.21 & 15.52 & $0.0056^{\star \star}$ \\
\hline $\mathrm{BC}$ & 90.25 & 1 & 90.25 & 5.40 & 0.0530 \\
\hline$A^{2}$ & 1474.74 & 1 & 1474.74 & 88.31 & $<0.0001^{* *}$ \\
\hline $\mathrm{B}^{2}$ & 26.63 & 1 & 26.63 & 1.59 & 0.2471 \\
\hline$C^{2}$ & 56.56 & 1 & 56.56 & 3.39 & 0.1083 \\
\hline Residual & 116.90 & 7 & 16.70 & & \\
\hline Lake of fit & 88.37 & 3 & 29.46 & 4.13 & 0.1021 \\
\hline Pure error & 28.53 & 4 & 7.13 & & \\
\hline Cor total & 3518.64 & 16 & & & \\
\hline
\end{tabular}

${ }^{\star \star}$ extreme significant difference $(p<0.01)$ 

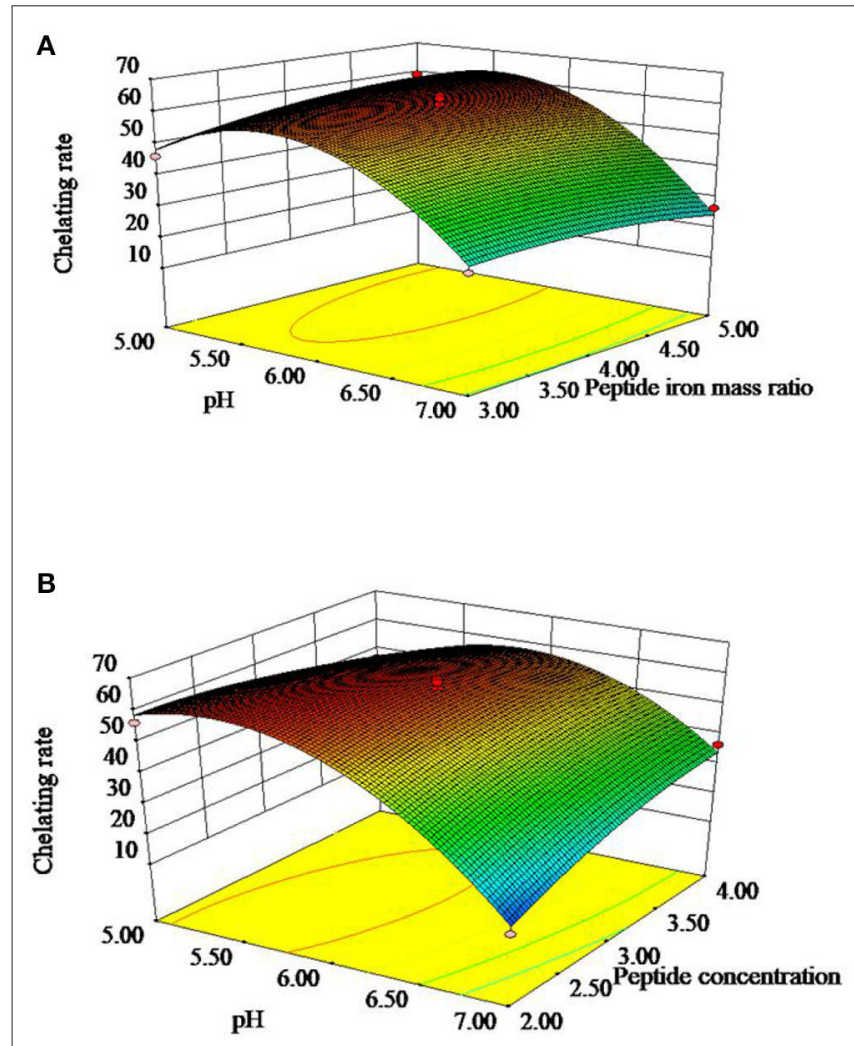

C

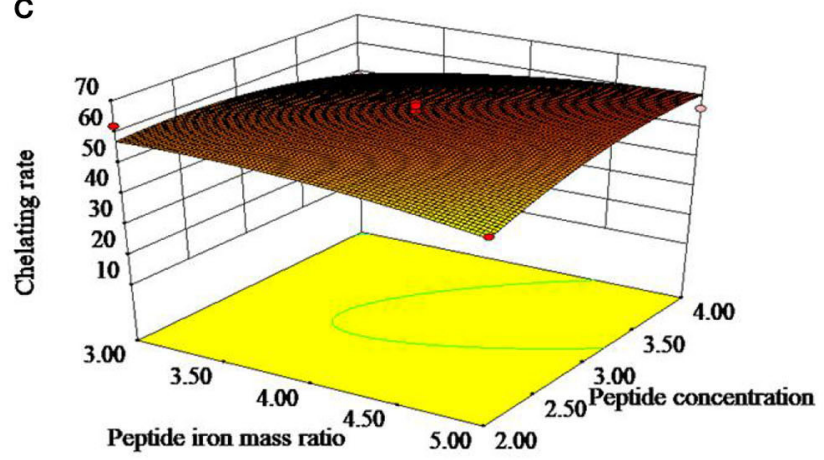

FIGURE 2 | Response surface plots showing effect of peptide concentration, $\mathrm{pH}$, and peptide iron mass ratio on chelating rate of $\mathrm{OP}-\mathrm{Fe}^{2+}$.

after OP-Fe ${ }^{2+}$ treatment for 2 weeks. As shown in Figure 5D, after 3 weeks, each treated group reached the normal MCHC level. The results of hematological indices indicated that OP$\mathrm{Fe}^{2+}$ could improve the hematological indices of rats caused by anemia.

\section{Serum Iron, Total Iron Binding Capacity, and Serum Ferritin Level of Rats}

Serum iron, iron binding capacity, and serum ferritin levels are useful parameters for the clinical diagnosis of iron deficiency anemia. In the MG group, the content of serum iron (SI) and serum ferritin (SF) was significantly lower than that in the CG and FG groups [(Figures 6A, 5B), $p<0.01$ ], Then, the SI level increased after OP-Fe ${ }^{2+}$ treatment, and there is no significant difference between the OPFL, OPFM, and CG groups $(p>0.05)$. As shown in Figure 6B, no significant differences in SF results were found between the CG group and the OPFL, OPFM, and FG groups $(p>0.05)$. The data of TIBC showed that the MG increased by $54.3 \%$ when compared with the CG group (Figure 6C, $p<0.01$ ). However, OP-Fe ${ }^{2+}$ treatment obviously inhibited the change, and each treatment group reached the normal TIBC content. These results showed that $\mathrm{OP}-\mathrm{Fe}^{2+}$ could effectively recover SI, SF, and TIBC levels in rats.

\section{Analysis of Antioxidant Activity in vivo}

$\mathrm{GSH}$ is a type of antioxidant peptide in organisms, which can reflect the antioxidant capacity of the body. As shown in Figure 7A, the GSH activity of the OPFL, OPFM, OPFH, and FG groups was significantly higher than that of the MG group $(p<0.05)$, and there was no significant difference when compared with the CG group $(p>0.05)$. Furthermore, no significant difference was observed between the OPFL and FG groups $(p>0.05)$. SOD is an important antioxidant enzyme, and it could prevent damage produced by free radicals (21). As shown in Figure $7 \mathbf{B}$, the SOD activity of rats in the MG group was significantly lower $(p<0.05)$ than that of the CG group. Meanwhile, the SOD activities of the OPFH and FG groups had no significant differences when compared with the CG group $(p>0.05)$.

Malondialdehyde is a lipid peroxidation metabolite. It can generally serve as an indicator of a generation of free radicals and of damage to the membrane lipid bilayer (22). As shown in Figure 7C, compared with the CG group, iron deficiency markedly increased MDA content in liver homogenate $(p<$ 0.05). After OP-Fe ${ }^{2+}$ supplementation, the MDA content of the OPFM and OPFH groups was significantly lower than that of the MG group $(p<0.05)$, and it returned to the normal level.

\section{Liver Function Test}

The evaluation of ALT and AST is utilized as a significant diagnostic marker to indicate liver injury. As is shown in Figure 8, the content of AST in the MG group was higher than that in the CG and FG groups $(p<0.01)$. After OP-Fe ${ }^{2+}$ treatment, the ALT level was decreased, and the ALT level in the OP-Fe ${ }^{2+}$ and $\mathrm{FG}$ groups did not significantly differ from that in the CG group $(p>0.05)$.

\section{DISCUSSION}

According to the Global Burden of Disease Study 2016, iron deficiency anemia is one of the five leading causes of years lived with disability burden. A worldwide survey showed that anemia has affected one-third of the population, and in 2010, approximately half of the cases resulted from iron deficiency (4). Iron deficiency anemia rarely causes death, but it is harmful to 

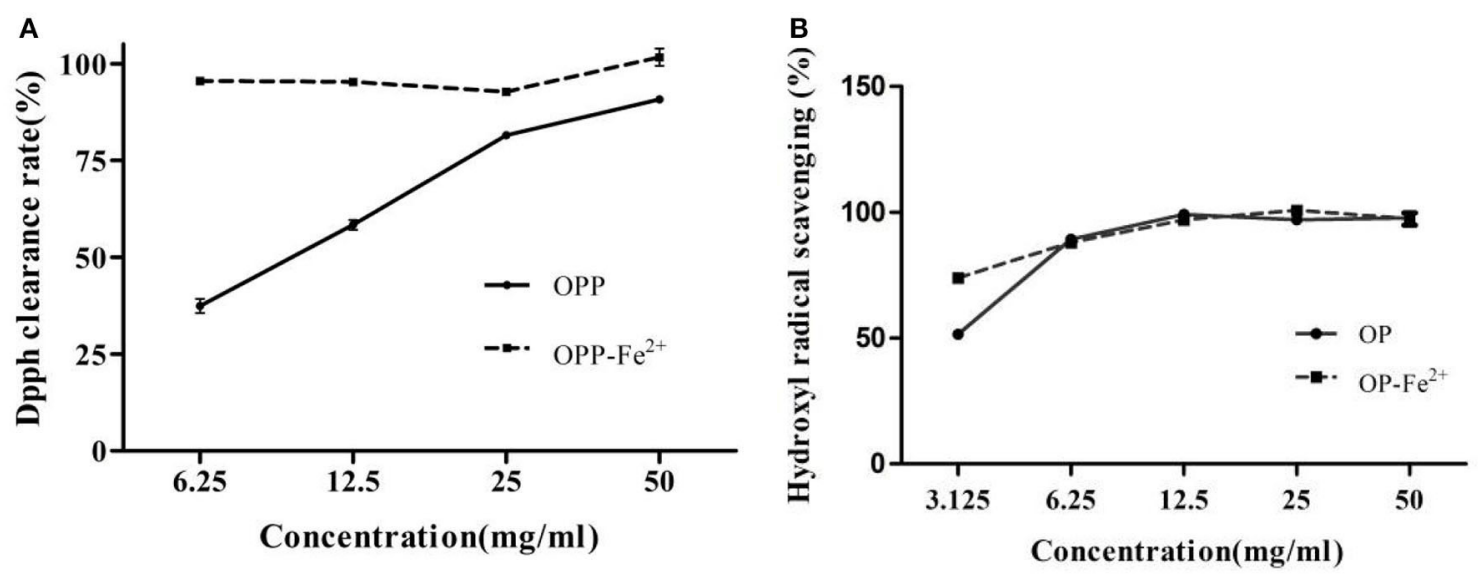

FIGURE 3 | The antioxidant activities of the OP and OP- $\mathrm{Fe}^{2+}$ (A) DPPH free radical scavenging activity and (B) hydroxyl radical scavenging activity.

TABLE 5 | The body weight (g) of rats in different groups with time of iron supplementation.

\begin{tabular}{|c|c|c|c|c|c|}
\hline Group & \multicolumn{5}{|c|}{ Day of experiment } \\
\hline$C G$ & $62.62 \pm 5.79^{a}$ & $291.51 \pm 12.24^{\mathrm{a}}$ & $337.56 \pm 18.41^{\mathrm{a}}$ & $367.65 \pm 22.64^{a}$ & $375.51 \pm 23.78^{a}$ \\
\hline OPFL & $62.19 \pm 4.73^{a}$ & $265.31 \pm 15.6^{b}$ & $302.20 \pm 21.95^{\mathrm{bc}}$ & $336.3 \pm 23.86^{b c}$ & $359.15 \pm 27.97^{a}$ \\
\hline OPFM & $63.39 \pm 9.39^{a}$ & $254.35 \pm 19.28^{b}$ & $302.50 \pm 22.93^{b c}$ & $334.43 \pm 23.37^{\mathrm{bc}}$ & $360.18 \pm 25.59^{a}$ \\
\hline
\end{tabular}

Data are presented as mean $\pm S D(n=10)$. Different letters in the same column indicate a significant difference between different groups $(p<0.05)$. The same letter in in the same column indicates the absence of a statistical difference between different groups $(p>0.05)$. $28 d$ refers to the time when the IDA model was successfully established and has not yet been given treatment; 35 d refers to the second week of treatment with $\mathrm{OP}-\mathrm{Fe}^{2+}$ and $\mathrm{FeCl}_{2} ; 42 \mathrm{~d}$ refers to the second week of treatment with $\mathrm{OP}-\mathrm{Fe}^{2+}$ and FeCl$; 52 \mathrm{~d}$ refers to the 3 weeks and 3 days of treatment with $\mathrm{OP}-\mathrm{Fe}^{2+}$ and $\mathrm{FeCl}_{2}$.
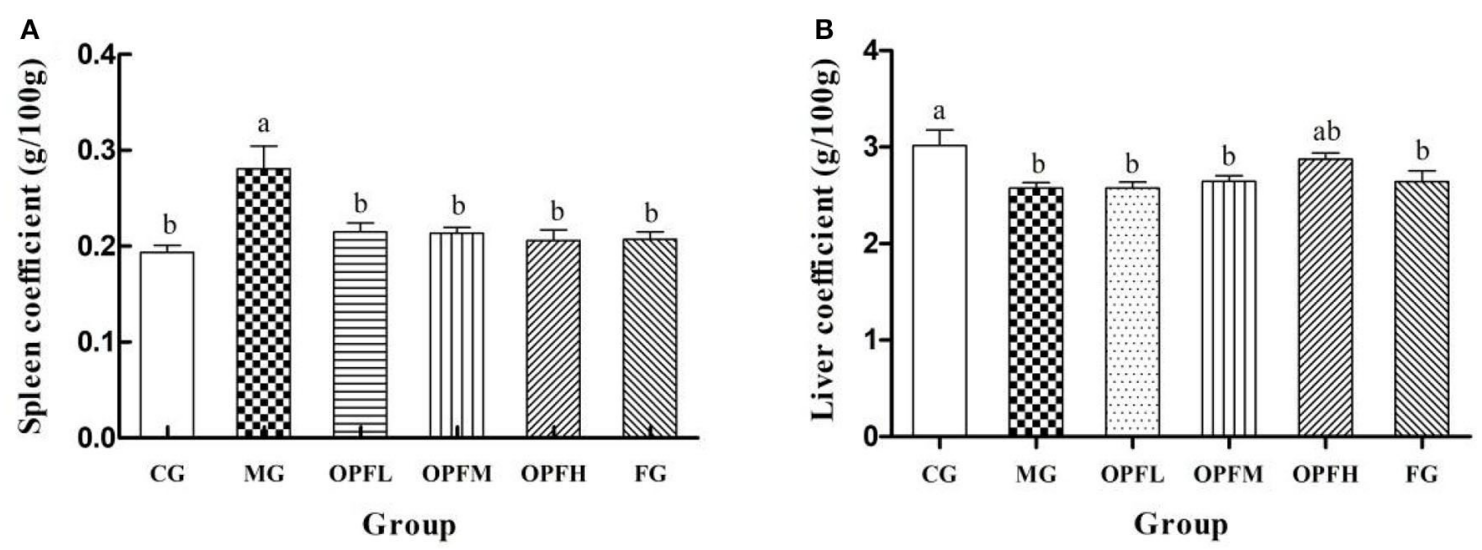

FIGURE 4 | Effects of different doses of OP- $\mathrm{Fe}^{2+}$ and $\mathrm{FeCl}_{2}$ on (A) spleen coefficient and (B) liver coefficient in IDA rats. Data are presented as mean $\pm \mathrm{SD}(n=10)$. The presence of two different letters in two groups indicate a statistical difference $(p<0.05)$ between them; the same letter in two different groups indicates the absence of a statistical difference between these two groups. 

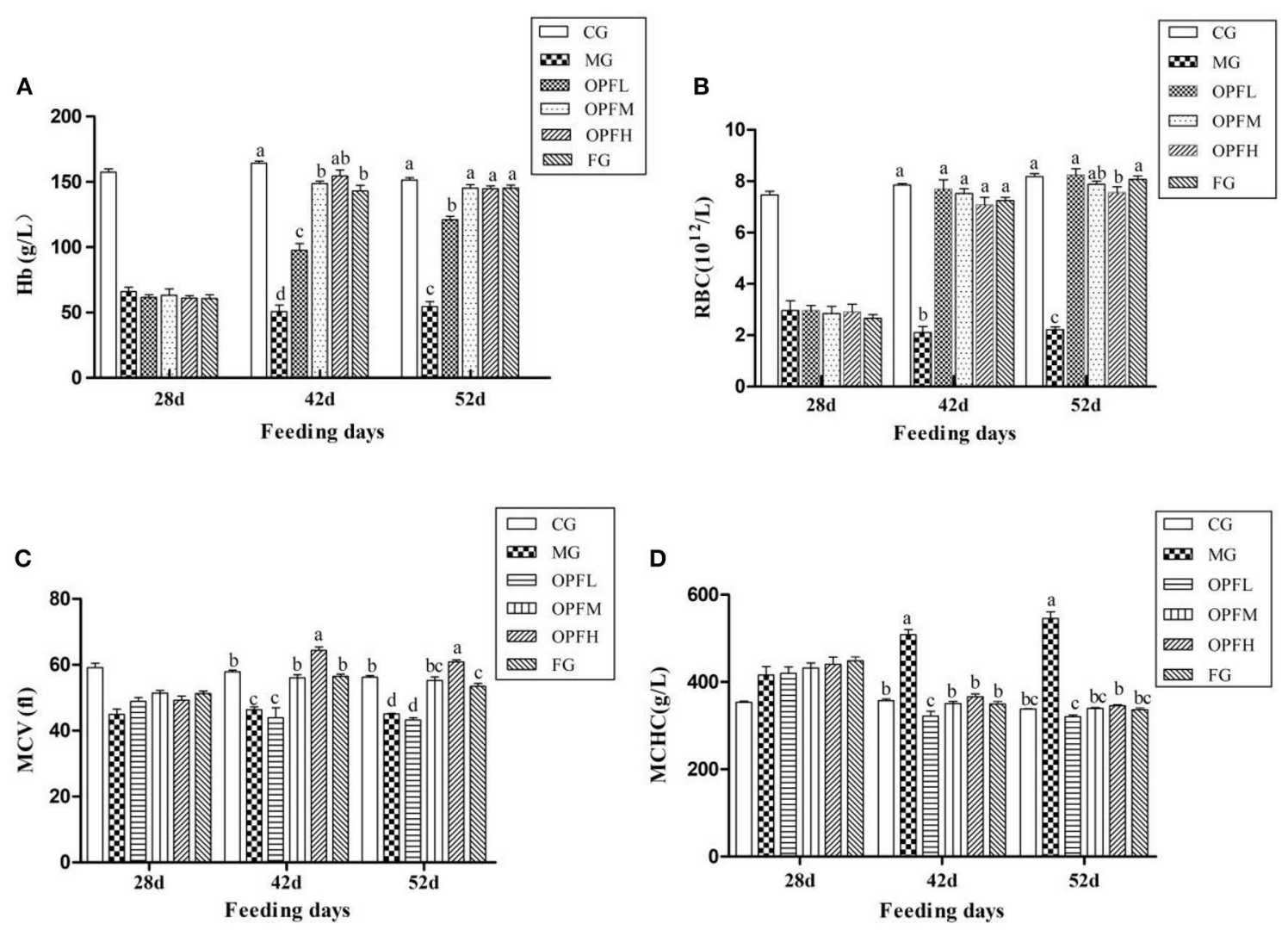

FIGURE 5 | Effect of different doses of $\mathrm{OP}-\mathrm{Fe}^{2+}$ and $\mathrm{FeCl}_{2}$ on (A) $\mathrm{Hb}$, (B) RBC, (C) MCV, and (D) MCHC in IDA rats. Different letters indicate a significant difference between different groups in the same period $(p<0.05)$. The same letter in different groups indicates the absence of a statistical difference between these groups in the same period ( $p>0.05)$. 28 d refers to the time when the IDA model was successfully established and has not yet been given treatment; $42 \mathrm{~d}$ refers to the second week of treatment with $\mathrm{OP}-\mathrm{Fe}^{2+}$ and $\mathrm{FeCl}_{2} ; 52$ d refers to the 3 weeks of treatment with $\mathrm{OP}-\mathrm{Fe}^{2+}$ and $\mathrm{FeCl}_{2}$.

human health. Although, several iron supplements have been in practice for the prevention of anemia since the past decades, there are still some problems, such as low bioavailability and side effects, which limit their clinical application. There is a need for an effective strategical approach that runs for a long time. Iron fortification in foods is a promising and cost-effective approach in targeting a particular group of people for the long run (23).

Food-derived bioactive peptides could be released from their native protein via enzymatic processing, which has the advantages of easy absorption and good biological activity. Meanwhile, some bioactive peptides prepared by the enzymatic method soften have a strong ability to chelate metals, and they can effectively deliver metals across the epithelial wall (24). Therefore, this study aimed to synthesize a new type of OP$\mathrm{Fe}^{2+}$ using $\mathrm{OP}$ as the carrier, and then the animal experiment was designed to evaluate the iron supplement effect of OP-Fe ${ }^{2+}$ on iron deficiency anemia (IDA) in rats. It has been reported that rats with IDA had low hemoglobin, low serum ferritin, and high TIBC level (25). In this study, we gained the same characters on the IDA model group. Then, after the application of $\mathrm{OP}-\mathrm{Fe}^{2+}$ diet, no significant differences in these parameters were observed between the normal group and the treated groups, which means that the OP-Fe ${ }^{2+}$ chelate had good iron supplement effects on the rats with IDA. Furthermore, the body weight changes and the organ coefficients results also indicated that the supply of OP-Fe ${ }^{2+}$ chelate could improve the body damage caused by IDA.

Iron is helpful to maintain homeostasis and regulate a wide variety of physiologic and metabolic pathways, such as oxygen transport, oxidative phosphorylation, and many other enzymatic pathways $(26,27)$. Besides, the dysregulation of iron pathways could lead to cellular oxidative stress (28). Oxidative stress is mainly attributed to the generation of hydroxyl radicals and the initiation of lipid peroxidation. Lipid peroxidation creates mutagenic reactants, such as aldehyde malondialdehyde (MDA) (27). Hydroxyl and superoxide anion radicals can easily react with carbohydrates, proteins, and DNA, leading to oxidative stress, cell injury, and physiological disorders, all damages of which are harmful to the human body (12). Antioxidant molecules have been considered as a strategy to prevent or reduce the incidence of many health-related conditions (29). It was reported that the antioxidant activity of chelates is higher than that of peptides. Lin et al. (30) pointed out that the free 

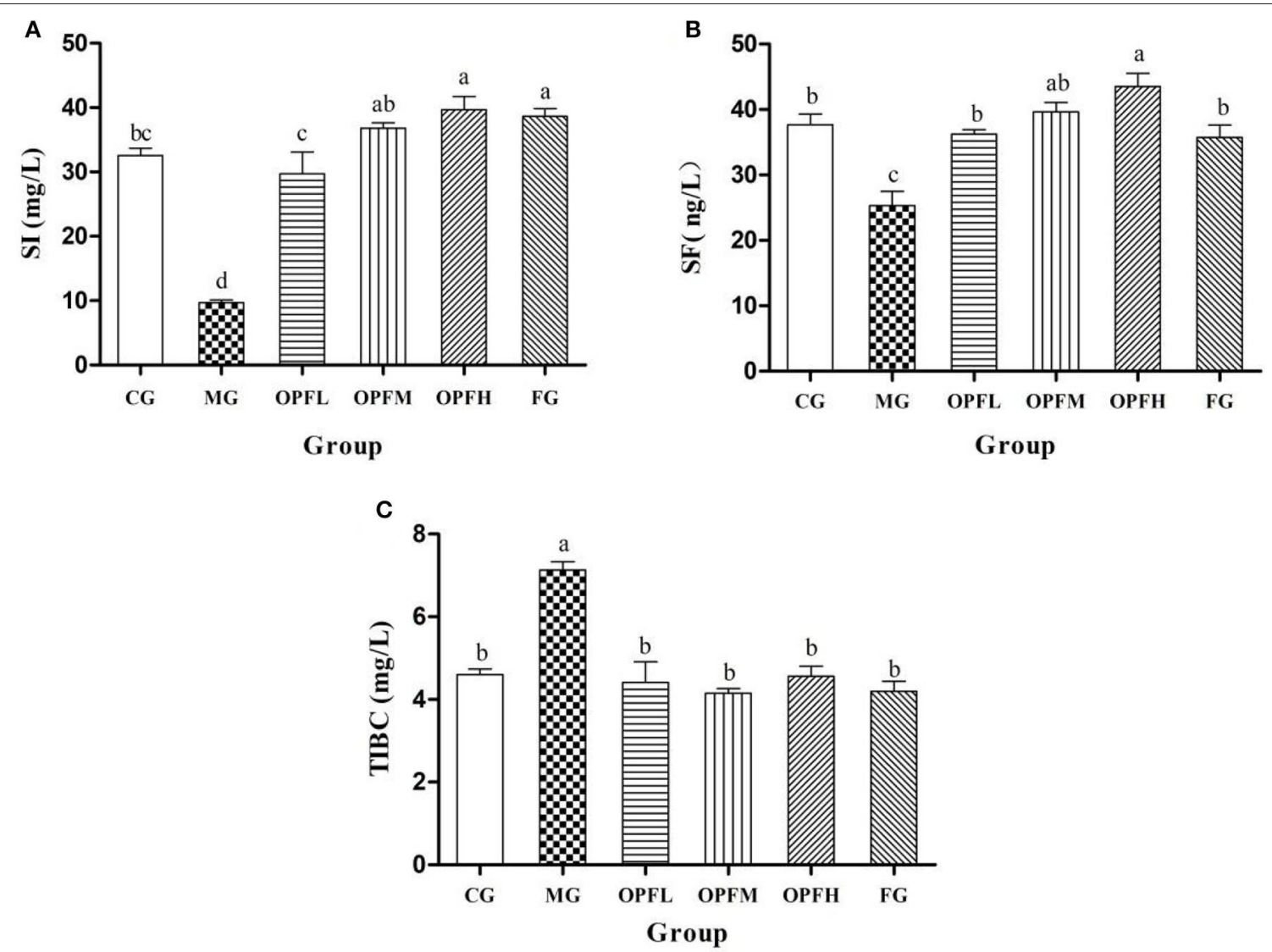

FIGURE 6 | Effect of different doses of OP- $\mathrm{Fe}^{2+}$ and $\mathrm{FeCl}_{2}$ on (A) SI, (B) SF, and (C) TIBC in IDA rats. Data are presented as mean $\pm \mathrm{SD}(n=10)$. Different letters show statistically significant differences $(p<0.05)$. The same letter in different groups indicates the absence of a statistical difference between these groups in the same period $(p>0.05)$.

radical scavenging activity of four low-value fish hydrolyzed peptides was weak, but $5 \mathrm{mg} / \mathrm{ml}$ hydrolyzed protein ferrous chelating peptides showed strong activity of scavenging DPPH radicals. In this study, for the in vitro antioxidant activity assays, $\mathrm{OP}-\mathrm{Fe}^{2+}$ showed stronger scavenging effects on hydroxyl radicals and DPPH than oat peptides, and the results showed that $\mathrm{OP}-\mathrm{Fe}^{2+}$ enhanced the antioxidant activity of OP. In addition, SOD and glutathione (GSH) are important factors in the prevention of oxidative stress through their action on reactive oxygen species (ROS) (21). In animal experiments, compared with those of anemic rats without $\mathrm{OP}-\mathrm{Fe}^{2+}$ supplementation, the activities of SOD and GSH in rats of OP- $\mathrm{Fe}^{2+}$ treated groups significantly increased. Moreover, OP- $\mathrm{Fe}^{2+}$ significantly reduced the MDA content in the liver of rats. Besides, AST results showed that $\mathrm{OP}-\mathrm{Fe}^{2+}$ could alleviate the hepatic injury caused by iron deficiency. These results suggested that OP$\mathrm{Fe}^{2+}$ was helpful in restoring the antioxidant capacity of anemic rats.

Though iron is biologically essential, its overload has potential toxicity including oxidative damage (31). In this study, we used the OPFL, OPFM, and OPFH groups treated with OP- $\mathrm{Fe}^{2+}$ to investigate the supplementary effect on iron deficiency in the IDA model. The results indicated that the OP- $-\mathrm{Fe}^{2+}$ of three different doses had good functions of iron supply, and no overload effect was detected. There are no significant side-effects on the OP$\mathrm{Fe}^{2+}$-treated group. We speculated that there are two probable reasons. The first one is the structure of $\mathrm{OP}-\mathrm{Fe}^{2+}$, a special combination of the oat peptides and iron, which regulates OP$\mathrm{Fe}^{2+}$ transportation and keeps iron absorption to meet the requirement of the body. The second reason may exist in the self-regulation of iron absorption, storage, and metabolism. The detailed regulatory process needs to be studied in the future. In addition, the molecular mechanism of the active application of $\mathrm{OP}-\mathrm{Fe}^{2+}$ chelate will be an interesting research direction, including the association between the OP- $-\mathrm{Fe}^{2+}$ and ROS and immune (32-34).

\section{CONCLUSION}

In this study, the preparation technology of $\mathrm{OP}-\mathrm{Fe}^{2+}$ was optimized. After chelating with iron, the antioxidant capacity 

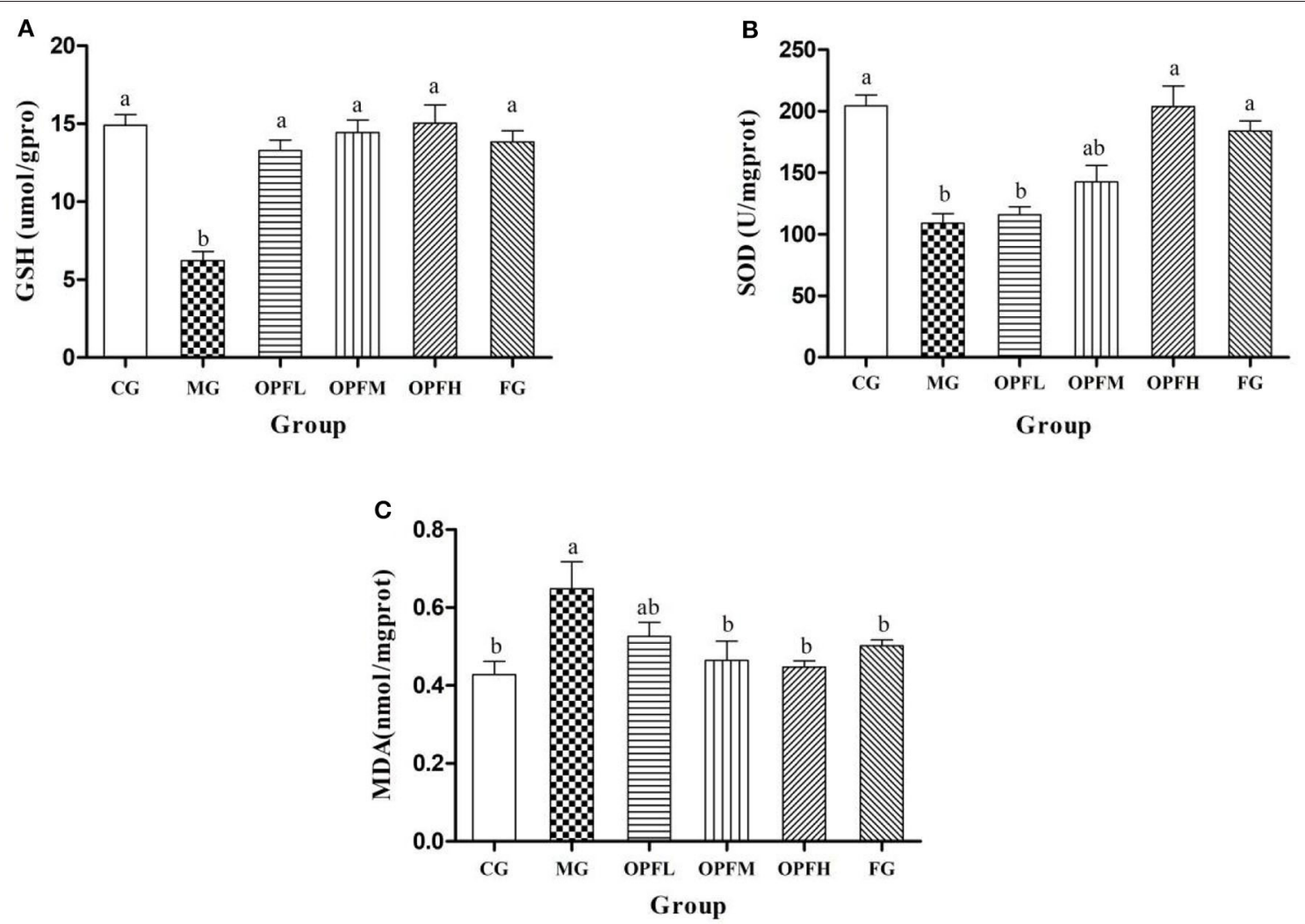

FIGURE 7 | Effects of different doses of OP- $\mathrm{Fe}^{2+}$ and $\mathrm{FeCl}_{2}$ on antioxidant activity in liver. (A) GSH content, (B) SOD activity, and (C) MDA content. Dates are presented as mean $\pm S D(n=10)$. The presence of different letters in different groups indicate a statistical difference $(p<0.05)$ between them; the same letter in different groups indicates the absence of a statistical difference between these groups $(p>0.05)$.
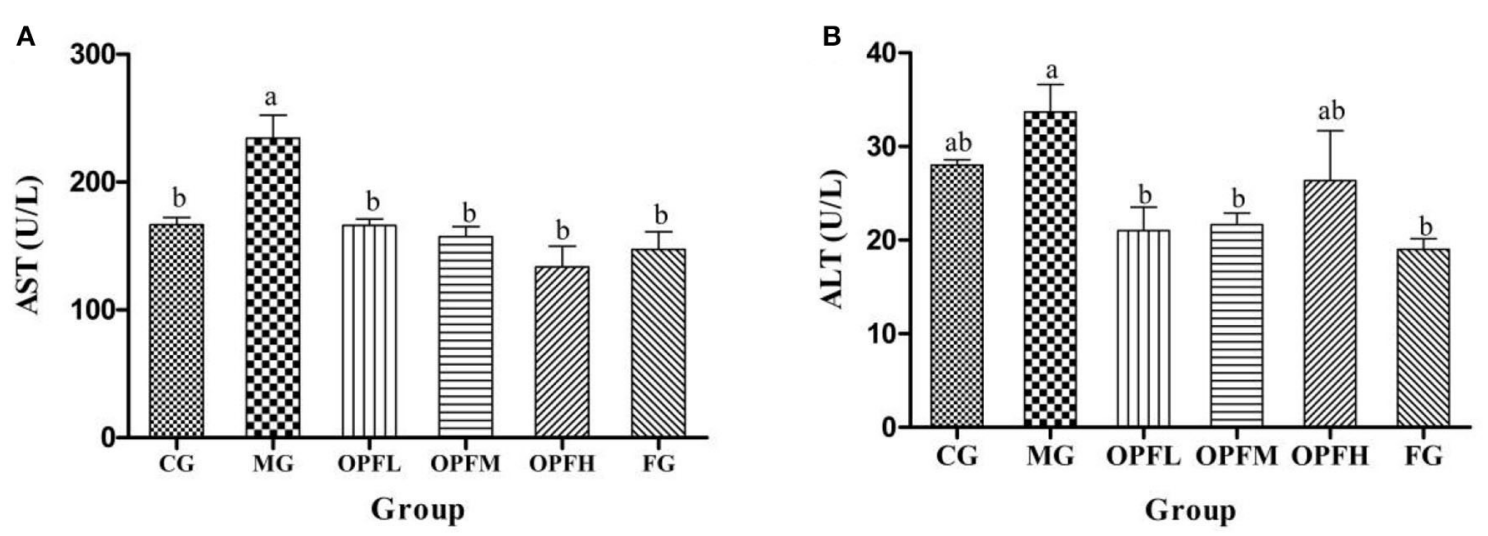

FIGURE 8 | Effects of different doses of $\mathrm{OP}-\mathrm{Fe}^{2+}$ and $\mathrm{FeCl}_{2}$ on (A) AST and (B) ALT levels in serum. Different letters show statistically significant differences ( $p<$ 0.05). The same letter in different groups indicates the absence of a statistical difference between these groups $(p>0.05)$. The same is true in ALT.

of oat peptides was significantly enhanced. The animal experiment indicated that $\mathrm{OP}-\mathrm{Fe}^{2+}$ can be used as an effective iron supplement and antioxidant. The regulation mechanism of $\mathrm{OP}-\mathrm{Fe}^{2+}$ in the restoration of the antioxidant capacity in rats is still unclear. Further studies are necessary to be conducted.

\section{DATA AVAILABILITY STATEMENT}

The original contributions presented in the study are included in the article/supplementary material, further inquiries can be directed to the corresponding author/s. 


\section{ETHICS STATEMENT}

The animal study was reviewed and approved by Institutional Animal Care and Use Committees of Jiangsu University (UJS-IACUC2020072201).

\section{AUTHOR CONTRIBUTIONS}

HY and YP contributed to conception and design of the study and wrote the first draft of the manuscript. HY organized the database. HY and DYa embellished the article. YP, CM, DYu, and GR performed the statistical analysis. YP and CM carried out specific experiments. HY, DYa, ZH, MH, and DYu wrote

\section{REFERENCES}

1. Wu W, Yang Y, Sun N, Bao Z, Lin S. Food protein-derived iron-chelating peptides: the binding mode and promotive effects of iron bioavailability. Food Res Int. (2020) 131:108976. doi: 10.1016/j.foodres.2020.108976

2. Harahap H, Jahari AB, Husaini MA, Saco-Pollitt C, Pollitt E. Effects of an energy and micronutrient supplement on iron deficiency anemia, physical activity and motor and mental development in undernourished children in Indonesia. Eur J Clin Nutr. (2000) 54:S114-9. doi: 10.1038/sj.ejcn.1601011

3. Cheng C, Huang DC, Zhao LY, Cao CJ, Chen GT. Preparation and in vitro absorption studies of a novel polysaccharide-iron (III) complex from Flammulina velutipes. Int J Biol Macromol. (2019) 132:801-10. doi: 10.1016/j.ijbiomac.2019.04.015

4. Camaschella C. Iron deficiency. Blood. (2019) 133:309. doi: 10.1182/blood-2018-05-815944

5. Xiao C, Lei X, Wang Q, Du Z, Jiang L, Chen S, et al. Effects of a tripeptide iron on iron-deficiency anemia in rats. Biol Trace Elem Res. (2016) 169:2117. doi: 10.1007/s12011-015-0412-6

6. Yuan B, Zhao C, Cheng C, Huang D-c, Cheng S-j, Cao C-j, et al. A peptide-Fe(II) complex from Grifola frondosa protein hydrolysates and its immunomodulatory activity. Food Biosci. (2019) 32:100459. doi: 10.1016/j.fbio.2019.100459

7. Lopez A, Cacoub P, Macdougall IC, Peyrin-Biroulet L. Iron deficiency anaemia. Lancet. (2016) 387:907-16. doi: 10.1016/S0140-6736(15)60865-0

8. Eckert E, Lu L, D.Unsworth L, Chen L, Xie J, Xu R. Biophysical and in vitro absorption studies of iron chelating peptide from barley proteins. J Funct Foods. (2016) 25:291-301. doi: 10.1016/j.jff.2016.06.011

9. Caetano-Silva ME, Bertoldo-Pacheco MT, Paes-Leme AF, Netto FM. Iron-binding peptides from whey protein hydrolysates: evaluation, isolation, and sequencing by LC-MS/MS. Food Res Int. (2015) 71:132-9. doi: 10.1016/j.foodres.2015.01.008

10. Ma X, Liu C, Song W, Che S, Wang C, Feng X, et al. Evaluating the efficacy of a ferrous-ion-chelating peptide from Alaska pollock frame for the improvement of iron nutritional status in rats. Food Funct. (2019) 10:488896 doi: 10.1039/C9FO00310J

11. Zhang T, Li YH, Miao M, Jiang B. Purification and characterisation of a new antioxidant peptide from chickpea (Cicer arietium L.) protein hydrolysates. Food Chem. (2011) 128:28-33. doi: 10.1016/j.foodchem.2011.02.072

12. Huang S, Lin H, Deng S-g. Study of anti-fatigue effect in rats of ferrous chelates including hairtail protein hydrolysates. Nutrients. (2015) 7:986071. doi: 10.3390/nu7125504

13. Esfandi R, Willmore W, Tsopmo A. Peptidomic analysis of hydrolyzed oat bran proteins, and their in vitro antioxidant and metal chelating properties. Food Chem. (2019) 279:49-57. doi: 10.1016/j.foodchem.2018.11.110

14. Yuanqing H, Min C, Lingling S, Quancai S, Pengyao Y, Rui G, et al. Ultrasound pretreatment increases the bioavailability of dietary proteins by sections of the manuscript. All authors contributed to manuscript revision, read, and approved the submitted version.

\section{FUNDING}

This work was supported by grants of National High Technology Research and Development Program 863 (No. 2013AA102203), Jiangsu University Foundation of China (No. 07JDG016), the Key Technology R\&D Program of Zhenjiang (No. SH2019011), and the Laboratory Animal Association Foundation of Jiangsu (No. DWXH201910).

\section{ACKNOWLEDGMENTS}

The authors are grateful to the reviewers for their constructive comments on the manuscript.

dissociating protein structure and composition. Food Biophys. (2020) 15:40915. doi: 10.1007/s11483-020-09634-y

15. Samtiya M, Aluko RE, Dhewa T, Moreno-Rojas JM. Potential health benefits of plant food-derived bioactive components: an overview. Foods. (2021) 10:839. doi: 10.3390/foods10040839

16. Cavazos A, de Mejia EG. Identification of bioactive peptides from cereal storage proteins and their potential role in prevention of chronic diseases. Compr Rev Food Sci F. (2013) 12:364-80. doi: 10.1111/1541-4337.12 017

17. Karas M, Jakubczyk A, Paczos-Grzeda E. Antioxidant properties of protein hydrolysates (Avena L.) from grains of cultivated and wild oat species. ZywnNauk Technol Ja. (2013) 20:106-17. doi: 10.15193/zntj/2013/91/106-117

18. Wu WM, He LC, Liang YH, Yue LL, Peng WM, Jin GF, et al. Preparation process optimization of pig bone collagen peptide-calcium chelate using response surface methodology and its structural characterization and stability analysis. Food Chem. (2019) 284:80-9. doi: 10.1016/j.foodchem.2019.01. 103

19. Xueyan T, Zhiyong H, Yanfeng D, Xiong YL, Mingyong X, Jie C. Peptide Fractionation and Free Radical Scavenging Activity of Zein Hydrolysate. $J$ Agric Food Chem. (2010) 58:587-93. doi: 10.1021/jf9028656

20. You L, Zhao M, Regenstein JM, Ren JJFC. In vitro antioxidant activity and in vivo anti-fatigue effect of loach (Misgurnus anguillicaudatus) peptides prepared by papain digestion. Food Chem. (2011) 124:18894. doi: 10.1016/j.foodchem.2010.06.007

21. Mansuroglu B, Derman S, Yaba A, Kizilbey K. Protective effect of chemically modified SOD on lipid peroxidation and antioxidant status in diabetic rats. Int J Biol Macromol. (2015) 72:79-87. doi: 10.1016/j.ijbiomac.2014.07.039

22. Forman HJ, Zhang H, Rinna A. Glutathione: overview of its protective roles, measurement, and biosynthesis. Mol Aspects Med. (2009) 30:112. doi: 10.1016/j.mam.2008.08.006

23. Shubham K, Anukiruthika T, Dutta S, Kashyap AV, Moses JA, Anandharamakrishnan C. Iron deficiency anemia: a comprehensive review on iron absorption, bioavailability and emerging food fortification approaches. Trends Food Sci Technol. (2020) 99:58-75. doi: 10.1016/j.tifs.2020. 02.021

24. Masubuchi Y, Suda C, Horie T. Involvement of mitochondrial permeability transition in acetaminophen-induced liver injury in mice. J Hepatol. (2005) 42:110-6. doi: 10.1016/j.jhep.2004.09.015

25. Auerbach M, Adamson JW. How we diagnose and treat iron deficiency anemia. Am J Hematol. (2016) 91:31-8. doi: 10.1002/ajh.24201

26. Vyoral D, Petrak J. Hepcidin: a direct link between iron metabolism and immunity. Int $J$ Biochem Cell Biol. (2005) 37:1768-73. doi: 10.1016/j.biocel.2005.02.023

27. Mintz J, Mirza J, Young E, Bauckman K. Iron therapeutics in women's health: past, present, and future. Pharmaceuticals. (2020) 13:449. doi: $10.3390 / \mathrm{ph} 13120449$ 
28. Khalid S, Ahmad SI. Correction of iron deficiency anemia in pregnancy and its effects on superoxide dismutase. Pak J Pharm Sci. (2012) 25:423-7. doi: 10.1177/0269881111398686

29. Esfandi R, Willmore WG, Tsopmo A. Antioxidant and anti-apoptotic properties of oat bran protein hydrolysates in stressed hepatic cells. Foods. (2019) 8:160. doi: 10.3390/foods 8050160

30. Lin H. Enzymatic Hydrolysis of Small Peptide Ferrous Chelate and its Biological Activity Study. Fuzhou: Fujian Agriculture and Forestry University (2012).

31. Camaschella C, Nai A, Silvestri L. Iron metabolism and iron disorders revisited in the hepcidin era. Haematologica. (2020) 105:260-72. doi: 10.3324/haematol.2019.232124

32. Verbon EH, Trapet PL, Stringlis IA, Kruijs S, Bakker P, Pieterse CMJ. Iron and immunity. Annu Rev Phytopathol. (2017) 55:355-75. doi: 10.1146/annurev-phyto-080516-035537

33. Gombart AF, Pierre A, Maggini S. A review of micronutrients and the immune system-working in harmony to reduce the risk of infection. Nutrients. (2020) 12:236. doi: 10.3390/nu12010236
34. Quiros Roldan E, Biasiotto G, Magro P, Zanella I. The possible mechanisms of action of 4-aminoquinolines (chloroquine/hydroxychloroquine) against SarsCov-2 infection (COVID-19): a role for iron homeostasis? Pharmacol Res. (2020) 158:104904. doi: 10.1016/j.phrs.2020.104904

Conflict of Interest: The authors declare that the research was conducted in the absence of any commercial or financial relationships that could be construed as a potential conflict of interest.

Copyright (C) 2021 Yuanqing, Pengyao, Yangyang, Min, Rui, Yuqing, Haihui and Haile. This is an open-access article distributed under the terms of the Creative Commons Attribution License (CC BY). The use, distribution or reproduction in other forums is permitted, provided the original author(s) and the copyright owner(s) are credited and that the original publication in this journal is cited, in accordance with accepted academic practice. No use, distribution or reproduction is permitted which does not comply with these terms. 